\title{
Logic model of the Recreovía: a community program to promote physical activity in Bogota
}

\section{Modelo lógico da Recreovia: um programa para a promoção da atividade física em Bogotá}

\author{
Ana P. Rios', Diana C. Paez', Edwin A. Pinzón², Rogério C. Fermino 3,4, Olga L. Sarmiento'
}

\begin{abstract}
This study aimed to develop the logic model of the Recreovía program in Bogota, Colombia. The logic model was developed based on the manual of the Center of Disease Control and Prevention (CDC), with indicators of resources, activities and short- and long-term results. Mixed methods were used for data collection and analysis. Human, physical and financial resources, as well as collaborators of the program, were identified, besides the activities defined according to the program aims. In conclusion, the program emphasizes the processes and actors for their operation and maintenance, and recognizes future challenges for physical activity promotion in Bogota.
\end{abstract}

\section{Keywords}

Motor activity; Physical fitness; Recreation; Green areas; Parks; Community Development.

\section{Resumo}

Este estudo objetivou desenvolver o modelo lógico do programa Recreovía de Bogotá, Colômbia. O modelo lógico foi desenvolvido com base no manual do Centro de Controle e Prevenção de Doença (CDC), com indicadores de recursos, atividades e resultados a curto, médio e longo prazo. Foram utilizados métodos mistos convergentes para a coleta e análise dos dados. Foram identificados os recursos humanos, físicos, financeiros e colaboradores do programa, além das atividades realizadas e resultados definidos de acordo com os objetivos do programa. Em conclusão, o programa ressalta os processos e atores para o seu funcionamento e manutenção, assim como identifica os desafios futuros para a promoção da atividade física em Bogotá.

\section{Palavras-chave}

Atividade motora; Aptidão física; Recreação; Áreas verdes; Parques recreativos; Desenvolvimento da comunidade.

\section{Introduction}

Physical activity programs in public open spaces have been described as promising interventions ${ }^{1,2}$. At the global level, programs in Australia, Canada, United States, India, New Zealand and South African have been described ${ }^{3}$. Community programs in public open spaces, such as parks and plazas, are a reality in Latin American countries for over 20 years, implemented in Argentina, Brazil, Chile, Colombia, Ecuador, Guatemala and Mexico ${ }^{3,4}$.

The Recreovía Program, created in Bogota (Colombia) in 1995, consists in sessions of physical activity, coordinated and musicalized, in plazas, parks,

1 University of Los Andes. School of Medicine. Group of Epidemiology of the University of los Andes (EpiAndes). Bogota D. C., Colombia.

2 District Institute for Recreation and Sport (IDRD). Bogota D. C., Colombia.

3 Federal University of Technology - Parana. Post-graduate Program in Physical Education. Research Group on Environment, Physical Activity and Health (GPAAFS). Curitiba-PR, Brazil.

4 Pontifical Catholic University of Parana. Research Group on Physical Activity and Quality of Life (GPAQ). Curitiba-PR, Brazil. commercial centers and jails ${ }^{2,5}$. This program promotes activities for the community ${ }^{3,6}$ and participation has been associated with higher physical activity levels, especially in women ${ }^{5}$.

The aim of this study was to develop a logic model of the Recreovía Program in Bogota, Colombia.

\section{Construction of the Logic Model}

The logic model was constructed based on the manual of the Center for Disease Control and Prevention of the United States ${ }^{7}$ during the months of July 2013 and December 2015. Three steps were taken: 1) identification of the needs or problems of the program; 2) identification of the actors in the program (beneficiaries, allies, counterparts); and 3) identification and analysis of the factors and indicators of the program. The key indicators were resources, activities and short- and long-term results ${ }^{7}$.

Mixed methods were used (qualitative and quan- 
titative $)^{8}$. The qualitative component included semi-structured surveys, conducted with participants experienced in the coordination of the program and documental revision. The participants included a current coordinator (2011-2016) and coordinators from three previous terms (1999-2004, 2005-2006, 2007-2010). The survey included questions on the structure of the program, users, instructors, physical activity sessions and budget and responses were recorded and transcribed ${ }^{6}$. Subsequently, five categories were created for coding: 1) resources, 2) activities, 3) outcomes, 4) short-term results and 5) long-term results ${ }^{7}$. Additionally, historical documents, official reports from governmental agencies and press releases were consulted.

The quantitative component included the construction of a database with historic number of users and instructors, budget and physical activity points in the Recreovía defined as spaces where the activities in the program were performed. The analysis was conducted with statistical software STATA 14.1.

The Project was approved by the ethics committee of the University of Los Andes (acta 161/2012). Verbal or written consent were given by participants.

\section{Logic Model of the Recreovía Program}

The Recreovía Program is coordinated by the technical sub management of recreation and sports of the Instituto Distrital de Recreación y Deporte (in English, District Institute for Recreation and Sport) (figure 1). The initial purpose was to complement the Ciclovia Recreativa Program, in which the streets are closed for automotive vehicles and open for recreational activities for the community. Currently, there are 41 points of the program (figure 2).
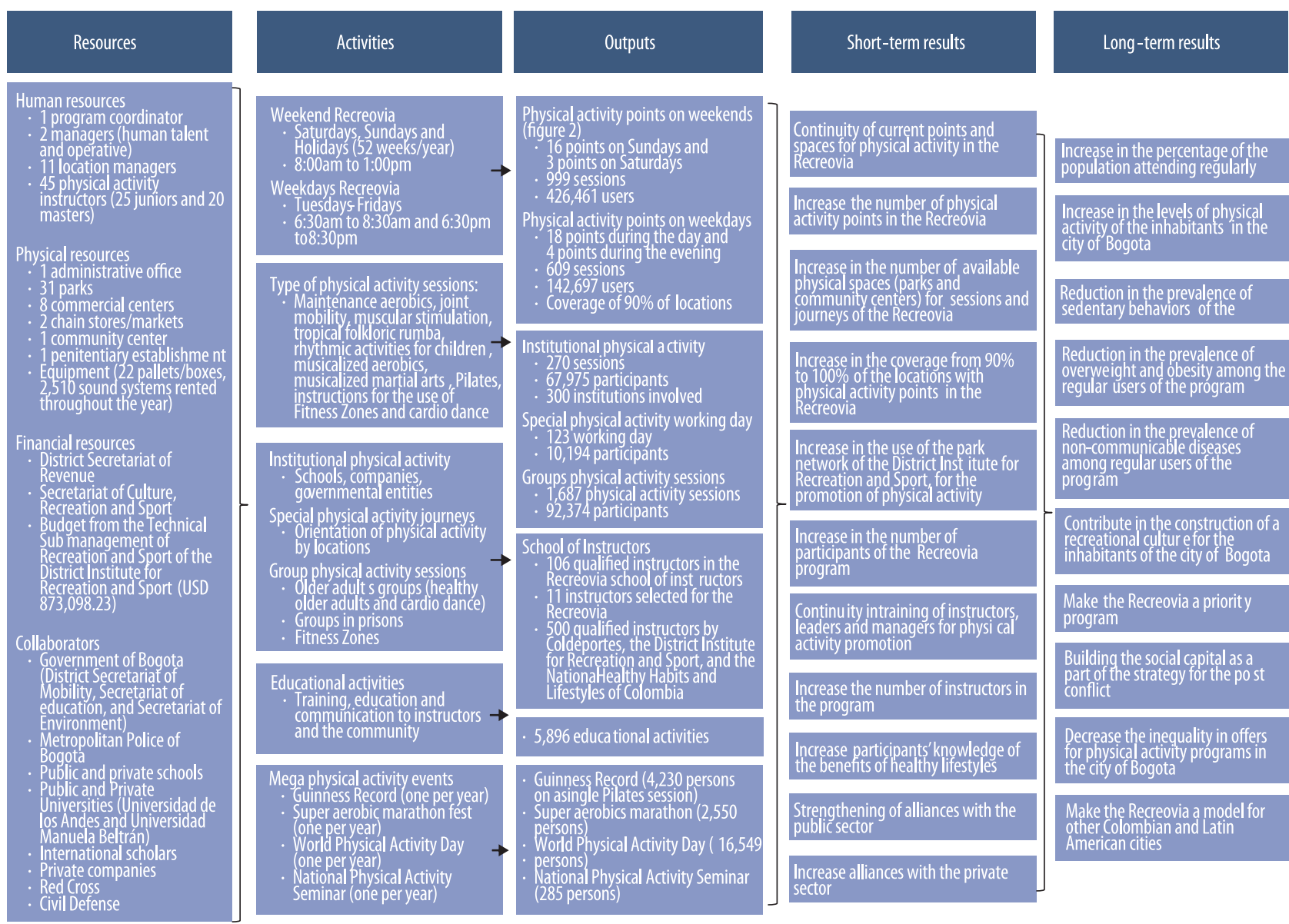
overweight and obesity amorn
regular users of the program
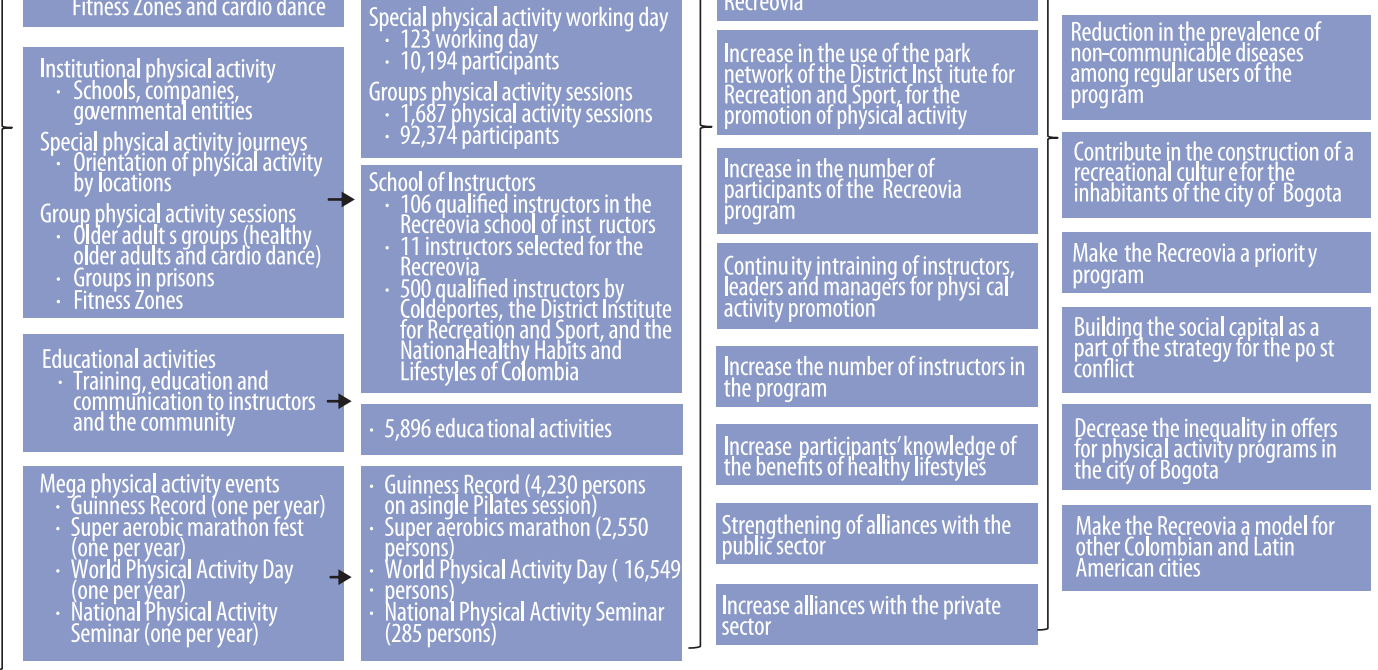

FIGURE 1 - Logic model of the Recreovía Program (initial purpose of the program: to complement the Ciclovia Recreativa program). 

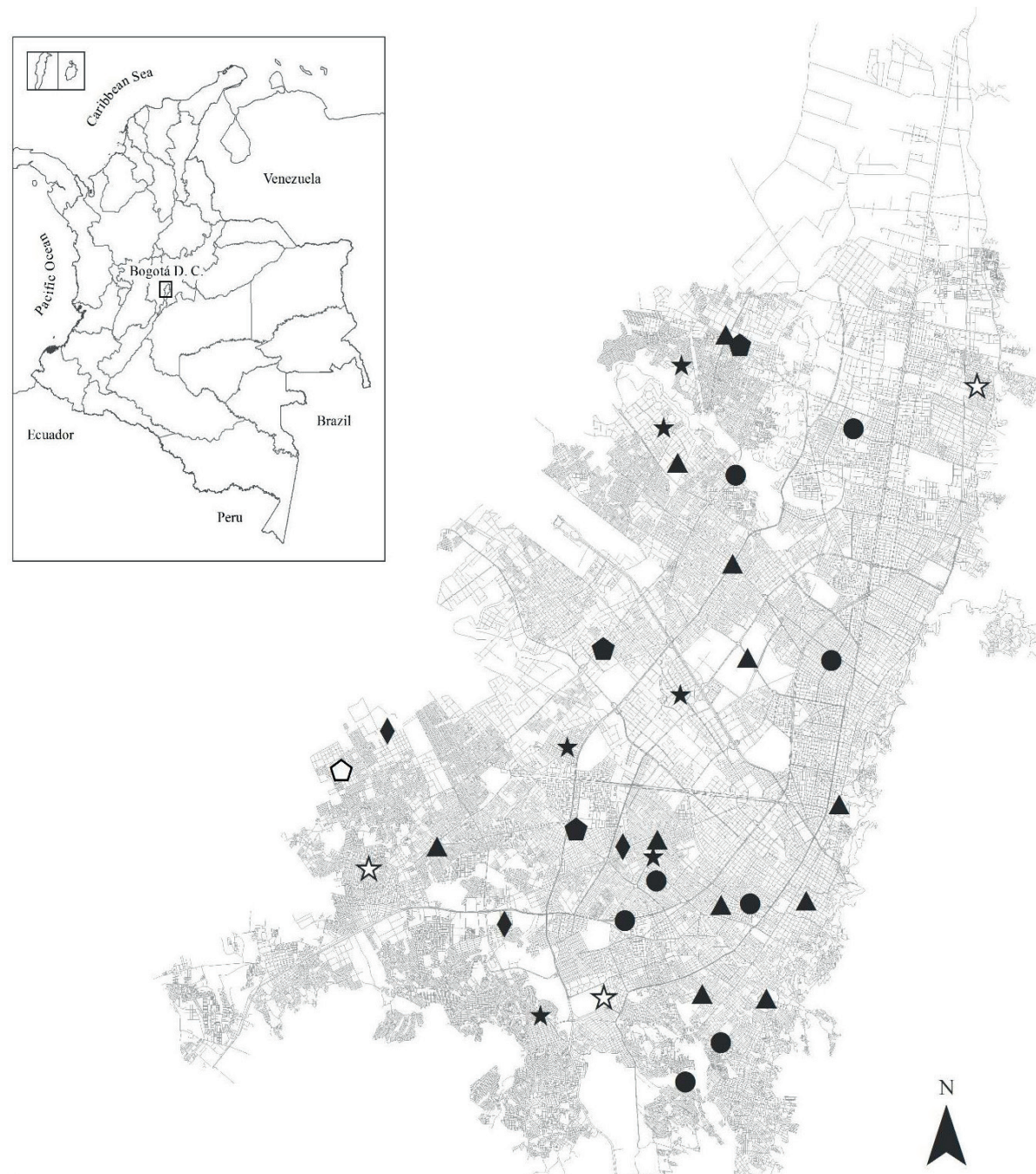

\section{Recreovías Schedule}

Sundays and Holidays $(n=12)$

Tuesdays and Thursdays $(n=9)$

Wednesdays and Fridays $(n=6$

Saturdays $(n=3)$

Tuesdays and Thursdays night $(n=3)$

Wednesdays and Fridays - Sundays and Holidauys $(n=6)$

Tuesdays and Thursdays night - Sundays and Holidays nights $(n=2$

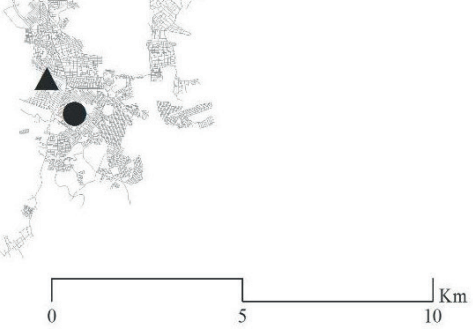

FIGURE 2 - Map of Bogota with points of the Recreovía Program ( $\mathrm{n=41).}$

\section{Resources}

Human resources include 59 people (figure 1). The coordinator manages the program, resources and responds to the different needs of the community. The human talent manager is responsible for managers and instructors, furthermore verifying the fulfillment of contract obligations of the physical activity points and managers. The technical operational manager organizes physical resources, service programming and technical support to the physical activity points. Instructors are selected through the Annual School of Physical Activity Instructors.

Physical resources include physical space with offices, places where activities of the Recreovía and the team are conducted. The spaces for physical activity sessions include a park network, commercial centers, chain stores/markets, community centers and a penitentiary building. The equipment for development of the 
sessions includes pallets/boxes (owned by the Institute of Recreation and Sport) and a sound system (rented by the hour to each of the events). In community centers, sound systems belong to the community.

Financial resources are provided by the District Secretariat of Revenue, which assigns resources to the Secretariat of Culture, Recreation and Sport, responsible for assigning it to the Technical Sub management of Recreation and Sports of the Institute of Recreation and Sport. The budget is used to account for administrative costs, hire personnel, rent equipment and purchase uniforms and materials. The amount funded by the district varies according to the period of government. In 2015, the total budget was USD 873,098.23.

Collaborators in the program belong to multiple sectors, public and private, in the city of Bogota. These entities include the Alcaldía Mayor of Bogota, District Secretariats, Metropolitan Police, schools, universities, private companies, Red Cross and Civil Defense. Local, national and international alliances have strengthened in the past years. These alliances strengthen the work networks, diffusion of program benefits and continuous capacitation.

\section{Activities}

The activities in the Recreovía are offered throughout the week, including Sundays and Holidays. On weekends, 19 physical activity points are available. On Saturdays, sessions are offered in three points from 8:00am to 10:00am. On Sundays, 16 points from 8:00am to 1:00pm (pilot test points from 9:00am to 12:00pm). During weekdays (day and night), there are 22 points where sessions are offered Tuesday through Friday. In the morning, sessions are present in 18 points (6:30am to $8: 30 \mathrm{am})$ and in the evening, four points $(6: 30 \mathrm{pm}$ to $8: 30 \mathrm{pm})$.

The types of activities include mainly sessions of maintenance aerobics, strength stimulation, joint mobility, rhythmic activities for boys and girls, tropical folkloric rumba, musical aerobics, musical martial arts and Pilates. Besides regular sessions, the Recreovía develops massive annual events by geographic locations. Special events mark the Summer Festival, World Physical Activity Day, Guinness Record and Aerobics Marathon. Also, special events, public or private, and special working day as a response to the community's wish. In parks where Fitness Zones (outdoor gyms) are available, instructors help users with correct use of equipment and complement the activity with an organized physical activity session. Additional groups sessions are offered, to increase opportunities of physical activity for vulnerable groups such as older adults and those inside a prison. During group sessions, the community also receives orientation on the importance of physical activity and healthy habits and lifestyles are stimulated through capacitation, education and communication strategies.

\section{Outcomes}

In 2015 , there were a total of 1,879 working day of physical activity and participation of 641,956 users. On weekends, 999 sessions were offered, with the participation of 426,461 users. On weekdays, a total of 609 sessions with 142,697 users were observed. Two massive events were conducted.

During the year of 2015, 106 instructors were trained in the School of Physical Activity Instructors and 11 were selected to work in the program. Additionally, along with the National Healthy Habits and Lifestyles Program, led by the Administrative Department of Sport, Recreation, Physical Activity and Leisure (COLDEPORTES), training was offered for over 500 instructors in Colombia. 


\section{Short-term results}

The short-term aims for the Recreovía Program are: at first, to increase the use of the park network, number of hired instructors, number of participants in the program to increase the knowledge of the benefits of healthy lifestyles in participants, as well as the points and physical spaces for physical activity to reach $100 \%$ of locations. Secondly, to continue with current points and spaces where activities are offered and training of instructors, leaders and managers for the promotion of physical activity. Finally, the strengthen alliances with the public and private sectors.

\section{Long-term results}

In the long-term, aims of the Recreovía are: first, to increase the percentage of the population regularly attending the program and increase levels of physical activity of the inhabitants of Bogota. Secondly, to decrease the prevalence of sedentary behavior, overweight/obesity and chronic disease among regular users, and the inequality in the offer of physical activity programs. Finally, to position the Recreovía as a priority program in the Government for the construction of social capital as part of the strategies as a model for other cities.

\section{Final considerations}

The logic model of the Recreovía highlights the processes and actors of the multiple sectors for its functioning and maintenance, focused on specific aims. The main goal of the program is to maximize social benefits in the community, reduce social inequality in health and access to programs, and improve the quality of life through the promotion of physical activity.

\section{Acknowledgments}

The authors thank the District Institute for Recreation and Sport for its collaboration in data collection, Adriana Díaz del Castillo for her comments in the manuscript and Karoll Quijano for her support with the layout of the map.

\section{Funding sources}

A. P. Rios received funds from the School of the Government of the University of los Andes and was partially sponsored by COLCIENCIAS during her Master's studies. This study was funded by the call on COLCIENCIAS \#453-2012 and the conjoint research call from the Fundación Santa Fe de Bogotá and Universidad of los Andes 2016.

\section{Authors' contributions}

Each author contributed individually and significantly to the development of this manuscript. A. P. Rios was responsible for the initial concept of the study, data collection, literature review, writing and revision of the manuscript in all its stages. D. C. Paez took part in data collection and initial writing of the manuscript. E. A. Pinzón participated in the creation and critical review of the logic model. R. C. Fermino participated in the initial concept of the study, literature review, writing and review of the manuscript in all its stages. O. L. Sarmiento was responsible for the concept of the project and participated in the writing and critical review of the manuscript in all its stages. All authors approved the final version of the manuscript. 


\section{References}

1. Ribeiro IC, Torres A, Parra DC, Reis RS, Hoehner C, Schmid TL, et al. Using logic models as iterative tools for planning and evaluating physical activity promotion programs in Curitiba, Brazil. J Phys Act Health. 2010;7(Suppl 2):S155-S162.

2. Pratt M, Brownson RC, Ramos LR, Malta DC, Hallal PC, Reis RS, et al. Project GUIA: a model for understanding and promoting physical activity in Brazil and Latin America. J Phys Act Health. 2010;7(Suppl 2):S131-S134.

3. Díaz Del Castillo A, González SA, Ríos AP, Paez DC, Torres A, Díaz MP, et al. Start small, dream big: experiences of physical activity in public spaces in Colombia. Prev Med. 2016; S0091-7435(16)30238-9.

4. Gámez R, Parra D, Pratt M, Schmid TL. Muévete Bogotá: promoting physical activity with a network of partner companies. Promot Educ. 2006;13(2):138-143.

5. Rios AP. Al ritmo de las comunidades: A natural experiment of the Recreovía program of Bogotá [Master's thesis]. Bogota D.C: Universidad de los Andes; 2016.

6. Paez DC, Reis RS, Parra DC, Hoehner CM, Sarmiento OL, Barros M, et al. Bridging the gap between research and practice: an assessment of external validity of communitybased physical activity programs in Bogotá, Colombia, and Recife, Brazil. Transl Behav Med. 2015;5(1):1-11.

7. U. S. Departament of Health and Human Services. Centers for Disease Control and Prevention (CDC). Physical Activity Evaluation Handbook. Atlanta, Georgia, GA. United States of America; 2006.

8. Creshwell JW, Plano Clark VL. Designing and conducting mixed methods research. Thousand Oaks, SAGE Publications; 2011.

\section{Corresponding}

Author

Ana Paola Rios

a-rios@uniandes.edu.co
University of Los Andes. Facult of

Medicine. Group of Epidemiology

EpiAndes.

Calle: Carrera 1 No 18A- 12 - Bogotá,

D.C., Colombia | Postal code: 111711

Telephone: (57-1) 3394949 ext 3785
RECEIVED 27/07/2016

APPROVED $03 / 10 / 2016$ 